\title{
The effect of replacement of cows gelatin by Cyprinus carpio skin gelatin on the some mineral contents and color parameters of functional pastill
}

\author{
N Choobkar ${ }^{1 *}$, A. R Aghajani ${ }^{2}$, A Jokar ${ }^{3}$ \\ ${ }^{1}$ Department of Fisheries, College of Agriculture, Kermanshah Branch, Islamic Azad University, Kermanshah, Iran \\ ${ }^{2}$ Department of food science and engineering, Faculty of Industrial and Mechanical engineering, Qazvin branch, \\ Islamic Azad University, Qazvin, Iran \\ ${ }^{3}$ Department of Food Science and Technology, Mahalat Branch, Islamic Azad University, Mahalat, Iran
}

Received: May 2018

Accepted: August 2018

\begin{abstract}
Gelatin is a valuable protein source and a commercial hydrocolloid which is particularly applied for food, pharmaceutical, and photographic industries. Commercial gelatin is basically from pig and cow, which because of religious reasons and risk of transmission of Bovine spongiform encephalopathy (BSE) respectively, not acceptable to use. Therefore gelatin extraction from fish, and especially it's waste has considerable importance. In the present study, after the extraction of gelatin from economic fish skin of carp (Cyprinus carpio), various formulations of this gelatin with cow's gelatin have been used in ratios of 0 , $25,50,75$ and $100 \%$ to pastill production.
\end{abstract}

*Correspondence N Choobkar, Department of Fisheries, College of Agriculture, Kermanshah Branch, Islamic Azad University, Kermanshah, Iran (e-mail: Nchoobkar20@gmail.com).
Then, the physicochemical experiments include of ash, protein, moisture, iron, phosphorus, zinc and lithium content, and color measurement were done on one day after of pastill production. The results showed that the treatment based on $75 \%$ fish gelatin had the highest moisture, protein, phosphorus, iron, ash and zinc content $(p<0.05)$ while the highest level of potassium and lithium content was related to treatment based on $100 \%$ industrial gelatin (Cow's) $(\mathrm{p}<0.05)$. Industrial treatment showed the highest $\mathrm{L}^{*}$ value (lightness) and the lowest index $\mathrm{a}^{*}$ (green-red) and $\mathrm{b}^{*}$ (blue-yellow) value $(p<0.05)$. It can be concluded that useless waste of fish as halal gelatin can be a good substitute instead of other gelatin for children's favorite junk foods, which has higher levels of zinc and protein content with economical benefits.

Keywords: pastill, fish skin gelatin, cow's gelatin, color measurement, physicochemical properties 


\section{Introduction}

Gelatin is a transparent and tasteless protein source and has a rheological property of thermo-reversible transformation between sol and gel which has been widely applied in food products, pharmaceutical, and photographic industries (Cho, Kwak, Park, Gu, Ji \& Jang, 2004). It's applications in food products are very broad including improving elasticity, consistency and stability of product. Gelatin is also applied as a thickening agent, certainly in dairy products (Giménez, B., Gómez-Guillén \& Montero 2005).

Gelatin is used in food formulation as foam and texture stabilizer and improve the water holding capacity and fat reduction (Nishimoto, Sakamoto, Mizuta \& Yoshinaka 2005, Karim \& Bhat 2009). Gelatin protein is obtained from collagen hydrolysis of animal skin or bone such as beef bone, hide, pig skin and more recently, pig bone and produced through thermal denaturation or collagen partial degradation of animal skin and bone (Hao, Li, Yang, Cen, Shi, Bo \& He 2009). The gel strength, viscosity, setting behaviour and melting point of gelatin depend on their molecular weight distribution and the amino acid composition, the imino acids proline and hydroxyproline are important in the renaturation of gelatin subunits during gelling (Mariod \& Adam 2013). Muslims refuse to consume all pig related products because of religious concerns and also they prohibite to consume of all cow-related products because of risk potential of transmission of bovine spongiform encephalopathy disease (BSE) that has long incubation period and the disease affects the nervous system of human. The fish processing industries generated a large amounts of waste which can be used in gelatin production due to low prices of them (Giménez et al., 2005). Some information was reported on gelatin processing through extraction and gelatin characteristic of skin and bone from cod (Gudmundsson \& Hafsteinsson 1997), black tilapia (Oreochromis mossambicus) and red tilapia (Oreochromis niloticus) (Bakar \& Harvinder 2002; Bakar, Tan, Hartina \& Ahmad 2011), hake (Montero, Borderıas, Turnay, and Lizarbe 1990), sin croaker (Johnius dussumieri), lumpfish (Osborne, Voigt, Hall 1990), megrim (Montero and Gomez-Guillen 2000) and shortfin scad (Decapterus macrosoma) (Cheow, Sarbon, Kyaw \& Howell 2007), grouper (Epinephelus sexfasciatus), yellow streaked snapper (Lutjanus lemniscatus), mackerel (Rastrelliger kanagurta), and sand bass (Morone chrysops) (Irwandi, Faridayanti, Mohamed, Hamzah, Torla \& Che Man 2009).

The purpose of this investigation was to determine the chemical composition of functional pastill in terms of mineral elements and color parameters, and to establish the relationships between industrial (cow) and fish gelatin skin.

\section{Materials and Methods}

\section{Fish samples}

The fish samples were obtained from Karaj fish market and transferred to Science and 
Technology Park Laboratory (Karaj, Alborz province) under appropriate temperature conditions. After entering the laboratory, frozen skins was washed with cold water immediately. Fish meat was removed using a knife. After washing, the skin was cleaned with cold water, then frozen again at $-20{ }^{\circ} \mathrm{C}$ and stored for further use. Then the frozen skin was cut into small pieces (about 2-3 centimeters square) while still frozen and were kept in a refrigerator $\left(4^{\circ} \mathrm{C}\right)$.

\section{Fish gelatin}

All gelatin manufacturing processes consist of three main stages: pretreatment of the raw material, extraction of the gelatin, and purification and drying. Depending on the method in which the collagens are pretreated, two different types of gelatin can be produced. Type A gelatin (isoelectric point at $\mathrm{pH}=6-9$ ) is produced from acid-treated collagen, and type $\mathrm{B}$ gelatin (isoelectric point at approximately $\mathrm{pH}$ = 5) is produced from alkali-treated collagen. Acidic treatment is most suitable for the less covalently crosslinked collagens found in pig or fish skins, while alkaline treatment is suitable for the more complex collagens found in bovine hides (Stainsby 1987). It should be noted that $1 \%$ guar gum as stabilizer was used.

\section{Sample preparations}

The gelatin extraction procedure followed was essentially as described by Grossman and Bergman (1992) with a little modifications. The cleaned and drained fish skins were given a pretreatment with an alkaline solution followed by an acid solution. Cleaned skins were taken in conical flask and treated with different concentrations of sodium hydroxide $(1: 6 \mathrm{w} / \mathrm{v})$ for variable times. The samples were then rinsed with tap water and drained using cheesecloth. The above treatment was repeated for 2 times. The samples were treated with different concentrations of sulphuric acid (1:6 $\mathrm{w} / \mathrm{v}$ ) for variable times. The samples were then rinsed with tap water and drained using cheesecloth. The acid treatment was also repeated two times. The treated samples were squeezed manually using cheesecloth to remove excess water prior to the extraction. The pretreated fish skins were taken in flasks for gelatin extraction with varying volumes of deionized water, extraction time and temperature. The flasks were covered with parafilm and the extraction was carried out in a water bath. Finally, the gelatin solutions were filtered through 4 layers of cheesecloth, and dried prior to further work (Mostafa, Shaltoit, Abdallah \& Osheba 2015).

\section{Pastill preparsion by gelatin}

To produce 100 grams of pastill, at first, gelatin was dissolved in distilled water (twice the gelatin weight) using a magnetic mixer at $60^{\circ} \mathrm{C}$ and to remove the air bubbles and clarification, the resulting mixture was placed in a hot water bath $\left(70{ }^{\circ} \mathrm{C}\right)$ (Abbasi, Mohammadi \& Rahimi 2011). At the next stage, glucose syrup (15 g), monohydrated dextrose powder (15 g) and sugar (35 g) with a few drops of distilled water was used to prepare sugar syrup. The mixture was heated to $120{ }^{\circ} \mathrm{C}$ and sugar syrup was prepared with brix $\% 80$. The sugar syrup was added to the gelatin solution after the temperature was reduced and the resulting mixture was placed in a warm bath $\left(70{ }^{\circ} \mathrm{C}\right)$ to 
remove the air bubbles completely. Then, to reach $\mathrm{pH}=3$, citric acid ( $1.5 \mathrm{~g})$ was added and mix slowly to prevent the entering the air bubbles (Demars et al. 2001). After mixing, a gelatin-sugar solution was poured into the mould and after being exposed to the oven (37 ${ }^{\circ} \mathrm{C} / 24 \mathrm{~h}$ ), it was exposed to ambient temperature for $24 \mathrm{~h}$ and then removed from the mould. The properties of the treatments are presented in Table 1.

Table 1. The characteristics of the treatments

\begin{tabular}{lll}
\hline Treatment & Cow's Gelatin & Fish gelatin \\
\hline S100 & 100 & 0 \\
S75 & 75 & 25 \\
S50 & 50 & 50 \\
S25 & 25 & 75 \\
S0 & 0 & 100 \\
\hline
\end{tabular}

\section{Physicochemical tests}

\section{Moisture measurement}

To determine the moisture content of the pastill, $10 \mathrm{~g}$ of each of the sample were placed in a glass plate, and then, transfered to the oven under a vacuum at $70^{\circ} \mathrm{C}$ and a pressure of 2.5 inches of mercury to reach a constant weight. After removing from the oven and weighting, moisture content based on wet weight was calculated from the equation 1 , where $\mathrm{W}_{\mathrm{m}}$ and $\mathrm{W}_{\mathrm{o}}$ are sample weight, respectively, before and after the incubation (Tsami 1990).

(Equation 1) Moisture $(\%)=\mathrm{W}_{\mathrm{m}}-\mathrm{W}_{\mathrm{o}} / \mathrm{W}_{\mathrm{m}}$

\section{Protein measurement}

In order to determine the protein content, the Kjeldahl method was used and three stages including digestion, distillation and titration were used. For this purpose, nitrogen content in the treatments was determined and then the protein content was obtained (ISIRI, NO.695).

\section{Potassium, iron and phosphorus measurement}

The measurements of potassium, iron and phosphorus were carried out by atomic light spectroscopy according to National Iranian Standard No. 9266. Then, the elements content was measured in the prepared solutions (ISIRI, NO.9266).

\section{Ash measurement}

A certain amount of sample was burnt in an electric furnace according to National Iranian Standard No. 2685 and the ash content was calculated (ISIRI, NO.2685).

\section{Color measurements}

The color of the pastill samples was measured using a Hunter $\mathrm{L}^{*} \mathrm{a}^{*} \mathrm{~b}^{*}$ colorimeter (Hunter Lab, Color Flex, USA). The results were expressed in accordance with the CIELAB uniform color system in terms of $\mathrm{L}^{*}$, lightness (values increase from 0 to $100 \%$ ); $a^{*}$, redness to greenness (positive to negative values, respectively) and $b^{*}$, yellowness to blueness (positive to negative values, respectively). The measurements were done at $20 \pm 5^{\circ} \mathrm{C}$ under constant light conditions and replicated 3 times (Khosravi Darani, Gholami \& Gouveia 2017).

\section{Statistical analysis}

Analysis of variance (ANOVA) was performed and means comparison was done using Duncan's multiple range tests for amino acid comparison between scales and gelatin data. Analysis was performed using SPSS ver. 24.0 for Windows (SPSS Inc., Chicago, IL, USA).

\section{Results}

\section{Moisture content}


According to Table 2, increasing the proportion of industrial (cow) gelatin, the moisture content (MC) of the samples decreased. The highest and lowest moisture content belonged to the treatment containing $100 \%$ fish gelatin and $100 \%$ industrial gelatin respectively. There was no significant difference between treatments with $75 \%$ gelatin content $(p>0.05)$, but difference with other treatments was significant (Table 2).

Table 2. The average comparsion of moisture content of treatments

\begin{tabular}{ll}
\hline Treatment & Moisture $(\%)^{*}$ \\
\hline S0 & $12.51 \pm 0.90^{\mathrm{a}}$ \\
S25 & $11.46 \pm 0.18^{\mathrm{b}}$ \\
S50 & $9.20 \pm 0.16^{\mathrm{d}}$ \\
S75 & $9.83 \pm 0.19^{\mathrm{c}}$ \\
S100 & $7.05 \pm 0.19^{\mathrm{c}}$
\end{tabular}

"Means \pm SD of triplicate determinations. Means with different superscript letters $(a, b, \ldots)$ show significant difference $(\mathrm{p}<0.05)$.

\section{Protein content}

According to Table 3, the highest protein content was found in the formulation containing $75 \%$ fish gelatin, which had a significant difference with other treatments $(\mathrm{p}<0.05)$. The lowest protein content related to the treatment containing the equal level of two which showed a significant difference between the protein content of this treatment and other treatments $(\mathrm{p}<0.05)$. No significant difference was observed between treatments containing 100\% fish gelatin, $100 \%$ and $75 \%$ industrial gelatin $(\mathrm{p}>0.05)$ (Table 3 ).

Table 3. The average comparsion of protein content of treatments

\begin{tabular}{lc}
\hline Treatment & Protein $(\%)^{*}$ \\
\hline S0 & $81.35 \pm 0.08^{\mathrm{ab}}$ \\
S25 & $82.39 \pm 0.14^{\mathrm{a}}$ \\
S50 & $80.33 \pm 0.20^{\mathrm{b}}$ \\
S75 & $81.08 \pm 0.49^{\mathrm{ab}}$ \\
S100 & $81.20 \pm 0.58^{\mathrm{ab}}$ \\
Means \pm SD of triplicate determinations. Means with \\
different superscript letters $(\mathrm{a}, \mathrm{b}, \ldots)$ show significant \\
difference $(\mathrm{p}<0.05)$.
\end{tabular}

\section{Potassium content}

Figure 1 shows the standard calibration curve of potassium which based on, the R-square $\left(\mathrm{R}^{2}\right)$ was 0.9067 (Fig 1). According to Table 4, treatment based on $100 \%$ industerial gelatin had the highest potassium content, which was not significantly different from treatment with equal levels of both types of gelatin ( $p>0.05)$, but it's difference with other treatments was quite significant $(\mathrm{p}<0.05)$. In general, a high proportion of industrial gelatin showed a higher potassium content (Table 4).

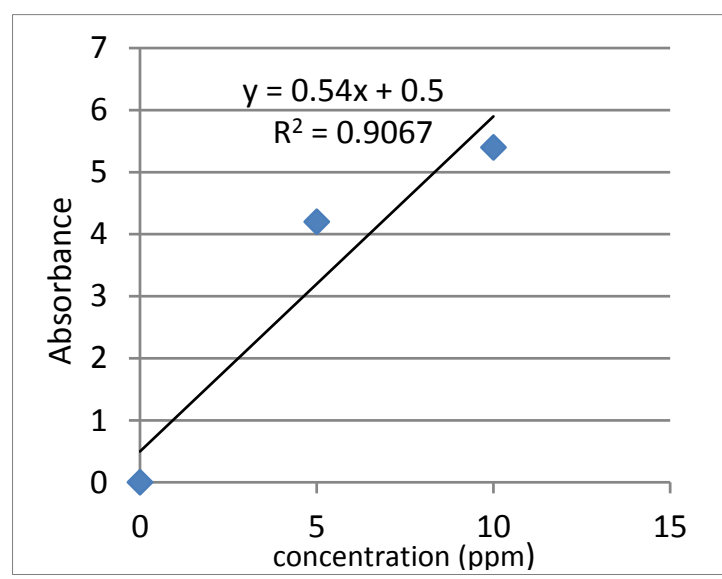

Figure1. The calibration curve of potassium standard

Table 4. The average comparsion of potassium content in treatments

\begin{tabular}{ll}
\hline Treatment & Potassium $(\%)^{*}$ \\
\hline S0 & $0.27 \pm 0.007^{\mathrm{b}}$ \\
S25 & $0.25 \pm 0.004^{\mathrm{c}}$ \\
S50 & $0.28 \pm 0.004^{\mathrm{a}}$ \\
S75 & $0.27 \pm 0.004^{\mathrm{b}}$ \\
S100 & $0.29 \pm 0.004^{\mathrm{a}}$ \\
\hline${ }^{*}$ Means \pm SD of triplicate determinations. Means with \\
different superscript letters $(\mathrm{a}, \mathrm{b}, \ldots)$ show significant \\
difference (p<0.05).
\end{tabular}

\section{Phosphorus content}

Figure 2 shows the standard calibration curve of phosphorus which based on the R-square $\left(\mathrm{R}^{2}\right)$ was 0.9407 (Fig 2). According to Table 5, by increasing the proportion of industrial gelatin from $25 \%$ to $100 \%$, the phosphorus content decreased. The highest phosphorus content 
related to the treatment containing $75 \%$ fish gelatin which there was a significant difference between this treatment and other treatments $(\mathrm{p}<0.05)$.

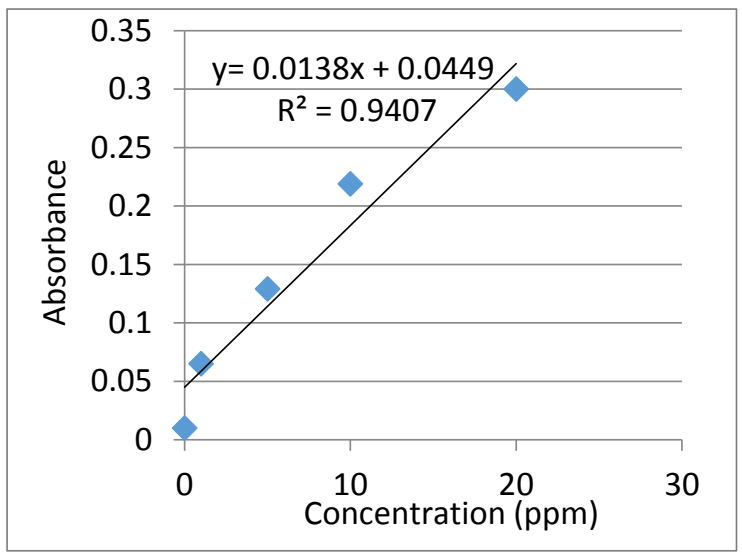

Figure 2. The calibration curve of phosphorus standard

In contrast, the lowest phosphorus content was related to $100 \%$ industrial gelatin, which did not differ significantly with treatment containing $75 \%$ of this gelatin ( $>>0.05)$, but it's difference with other treatments was significant $(\mathrm{p}<0.05)$ (Table 5). In present study, the highest phosphorus content belonged to the treatment containing $75 \%$ fish gelatin, which statistically showed a significant difference between this treatment and other treatments $(\mathrm{p}<0.05)$. In contrast, the lowest phosphorus content was related to $100 \%$ industrial gelatin, which did not differ significantly with treatment containing $75 \%$ of this type of gelatin $(\mathrm{p}>0.05)$.

Table 5. The comparsion average of phosphorus content in treatments

\begin{tabular}{ll}
\hline Treatment & Phosphorus (\%) \\
\hline S0 & $4.58 \pm 0.007^{\mathrm{b}}$ \\
S25 & $5.44 \pm 0.004^{\mathrm{a}}$ \\
S50 & $3.40 \pm 0.004^{\mathrm{c}}$ \\
S75 & $0.25 \pm 0.004^{\mathrm{d}}$ \\
S100 & $0.17 \pm 0.004^{\mathrm{d}}$ \\
\hline
\end{tabular}

${ }^{*}$ Means \pm SD of triplicate determinations. Means with different superscript letters $(a, b, \ldots)$ show significant difference $(\mathrm{p}<0.05)$.

\section{Iron content}

Figure 3 shows the standard calibration curve of iron which based on, the $\mathrm{R}$-square $\left(\mathrm{R}^{2}\right)$ was 0.9795 (Fig 3).

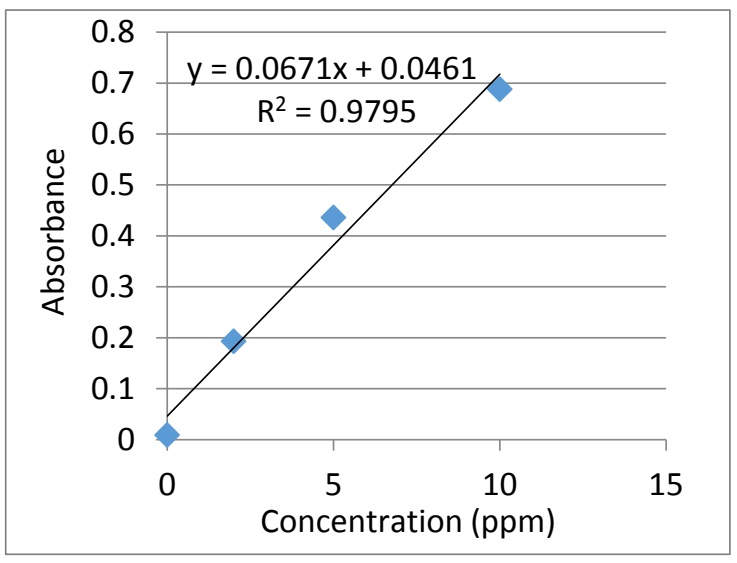

Figure 3. The calibration curve of iron standard

According to Table 6, higher levels of fish gelatin had more ferrous content. By increasing the proportion of industrial gelatin from 25 to $100 \%$, the trend of iron changes was declining. Therefore, the lowest iron content belonged to $100 \%$ industrial gelatin, which had a significant difference with other treatments $(\mathrm{p}<0.05)$, However, there was a significant difference between all treatments $(\mathrm{p}<0.05)($ Table 6$)$.

Table 6. The comparsion average of iron content in treatments

\begin{tabular}{ll}
\hline Treatment & Ferous $(\%)^{*}$ \\
\hline S0 & $0.044 \pm 0.0001^{\mathrm{b}}$ \\
S25 & $0.053 \pm 0.0001^{\mathrm{a}}$ \\
S50 & $0.038 \pm 0.0001^{\mathrm{c}}$ \\
S75 & $0.031 \pm 0.0001^{\mathrm{d}}$ \\
S100 & $0.027 \pm 0.0001^{\mathrm{e}}$ \\
\hline
\end{tabular}

${ }^{*}$ Means \pm SD of triplicate determinations. Means with different superscript letters $(a, b, \ldots)$ show significant difference $(\mathrm{p}<0.05)$.

\section{Ash content}

According to table 7, treatment based on $75 \%$ fish gelatin had the highest ash content and it's difference with other treatments was quite significant $(\mathrm{p}<0.05)$. The lowest ash amount 
belonged to the treatment containing $100 \%$ industrial gelatin, which had a significant difference with other treatments $(p<0.05)$. In general, the ash content was higher in treatments containing higher levels of fish gelatin (Table 7).

Table 7. The comparsion average of ash content of treatments

\begin{tabular}{lc}
\hline Treatment & Ash $(\%)^{*}$ \\
\hline S0 & $1.59 \pm 0.015^{\mathrm{b}}$ \\
S25 & $1.91 \pm 0.015^{\mathrm{a}}$ \\
S50 & $1.32 \pm 0.020^{\mathrm{c}}$ \\
S75 & $1.08 \pm 0.072^{\mathrm{d}}$ \\
S100 & $0.83 \pm 0.015^{\mathrm{e}}$ \\
\hline${ }^{*}$ Means \pm SD of triplicate determinations. Means with different \\
superscript letters $(\mathrm{a}, \mathrm{b}, \ldots)$ show significant difference $(\mathrm{p}<0.05)$.
\end{tabular}

\section{Color parameters ( $\left.L^{*} \mathbf{a}^{*} \mathbf{b}^{*}\right)$}

According to Fig. 4, the highest brightness ( $\mathrm{L}^{*}$ ) value was related to the treatment containing $100 \%$ industrial gelatin $(59.94 \pm 0.52)$, which had a significant difference with other treatments $(\mathrm{p}<0.05)$.

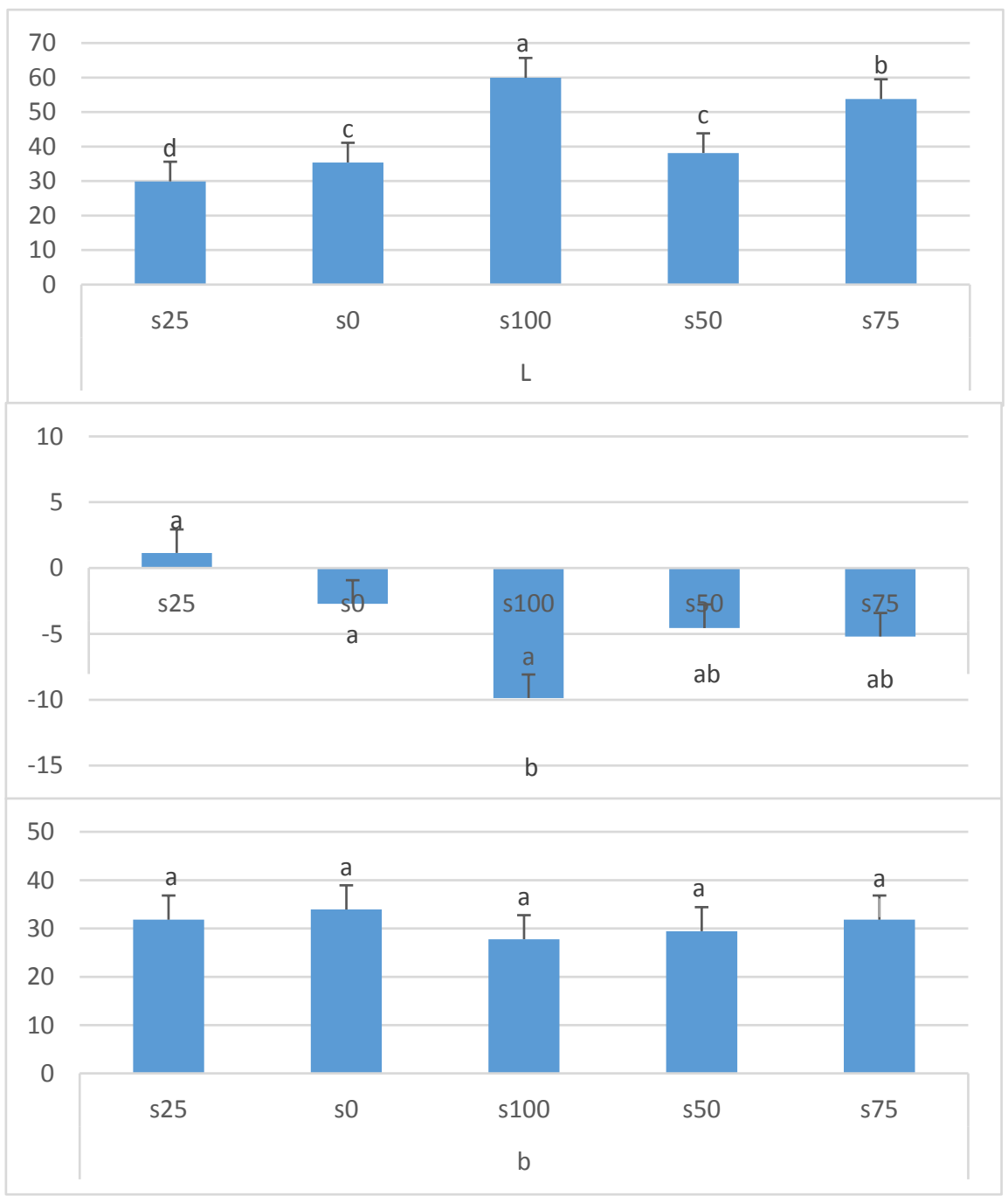

Figure 4. The comparsion average of color parameters $\left(\mathrm{L}^{*} \mathrm{a}^{*} \mathrm{~b}^{*}\right)$ of treatments 


\section{Discussion}

Fish gelatin as a halal source can replace gelatin derived from mammals in all industries, especially in food products and can be prepared from fish waste. In this paper, after the extraction of gelatin from economic fish skin of carp (Cyprinus carpio), various formulations of this gelatin with cow's gelatin have been used in ratios of $0,25,50,75$ and $100 \%$ to pastill production. Then, the physicochemical experiments include of ash, protein, moisture, iron, phosphorus content, and color measurement were done on one day after of pastill production.

The results showed that the highest and lowest moisture content belonged to the treatment containing $75 \%$ fish gelatin and $100 \%$ industrial gelatin respectively. Gelatin contains $8-13 \%$ moisture. When gelatin granules are soaked in cold water they hydrate into discrete, swollen particles (Finch \& Jobling 1977).

Moisture content is one of the most important quality factors of food (Pittia, Nicoli \& Sacchetti 2007; Reh, Gerber, Prodolliet \& Vuataz 2006). Elevated MC of stored foods is the important cause of growth of fungi. To be more exact, it is the thermodynamic water activity $\left(a_{w}\right)$ that limits activity of microorganisms. The water availability can also be explained in terms of the associated equilibrium relative humidity (ERH). Food products in contact with an atmosphere of a given relative humidity $(\mathrm{RH})$ or $\mathrm{a}_{\mathrm{w}}$ will come to (near) equilibrium at a $\mathrm{MC}$ that is based on the food composition (Chen 2000). Hansson,
Andersson and Leufven (2001) stated that when the pastill formulations have a very low water content, viscosity and water activity $\left(\mathrm{a}_{\mathrm{w}}\right)$ are two parameters that affect the diffusion and release of aromatic compounds. In the present study, the highest MC belonged to the treatment based on $75 \%$ fish gelatin, which has a significant difference with other treatments. Different MC in a products containing gelatin or gelatin-based foods can be due to the difference in extraction conditions (time, temperature ect.) and product type (Trindade Alfaro, Balbinot, Weber, Tonial \& MachadoLunkes 2015).

The highest protein content was found in the formulation containing $75 \%$ fish gelatin, which had a significant difference with other treatments $(p<0.05)$. Marine by-products such as fish wastes have been reported to be suitable sources for functional food ingredients (Barrow $\&$ Shahidi 2007). Fish by-products contain both valuable lipid and protein fractions as well as other compounds (Rustad, Storrø \& Slizyte 2011). Fish is increasingly demanded for use as food and feed. However, nutritional advantages of fish are limited by it's rapidly perishable nature and therefore short shelf-life (Jim, Garamumhango \& Musara 2017). Muyonga, Colec and Duodub (2004) reported that the protein content in the collagenous material represents the possible maximum yield of the gelatin. The main cause of the difference in qualitative properties of mammalian gelatin with fish gelatin can be observed in the absence of proline and hydroxyproline gelatin in the 
absence of amino acids in mammals gelatin (Haug, Draget, \& Smidsrod 2004). In this study, the lowest protein content belonged to the equal level of two kind of gelatin, which showed a significant difference between the protein content of this treatment and other treatments $(\mathrm{p}<0.05)$.

Treatment based on $75 \%$ fish gelatin had the highest ash content and it's difference with other treatments was significant $(\mathrm{p}<0.05)$. In general, the ash content was higher in treatments containing higher levels of fish gelatin (Table 7). The ash content in Grass carp gelatin was $0.12 \%$ (Kasankala, Xue, Weilong, Hong \& He 2007). The presence of ash and lipids in low amounts is considered very important for the quality of gelatin obtained. Ash is higher in bone and higher ash content, shows higher levels of minerals, which depends on the type of fish and extracted gelatin (Trindade Alfaro et al. 2014).

Regarding human nutrition, fish meat, in addition to large amount of easily assimilated animal protein and vitamins, is a valuable source of minerals (Lombardi-Boccia, Lanzi \& Aguzzi 2005) such as calcium, sodium, magnesium, potassium, iron, copper, manganese and zinc (Kunachowicz, Nadolna, Przygoda \& Iwanow 2005). The results showed that the treatment based on $75 \%$ fish gelatin had the highest phosphorus, iron and zinc content $(p<0.05)$ while the highest level of potassium and lithium content was related to treatment based on $100 \%$ industrial gelatin (Cow's) $(\mathrm{p}<0.05)$.
Potassium is an essential nutrient where it plays a key role in maintaining cell function particularly in important cells such as muscles and nerves. Potassium is a major intracellular ion that widely distributed in foods derived from living tissues (Weaver 2013). Fish are known for having abundant amounts of minerals, including phosphorus (El.Deen and El-Shamery 2010) and Iron (Jesu prabhu 2015). Iron is a component of haemoglobin and myoglobin, and is responsible for the transport of respiratory gases. Both $\mathrm{Zn}$ and $\mathrm{Fe}$ are absorbed from the food rich in animal protein better than from plant foods (Blicharski, Ksiazek, Pospiech, Migdał, Jozwik, Poławska \& Lisiak 2013).

Industrial treatment showed the highest $\mathrm{L}^{*}$ value (lightness) and the lowest index $a^{*}$ (green-red) and $\mathrm{b}^{*}$ (blue-yellow) value $(p<0.05)$. The sensory evaluation is crucial aspect to acceptability, and color is most important parameter in food specially junk food such as pastill. This sensory quality depends on the combination of some factors related to processing conditions, materials, storage, and facilities used (Curt, Trystram, NogueiraTerrones, \& Hossenlopp 2004). Many studies have shown that color curves can substantially impact upon human flavor perception (Levitan, Zampini, Li \& Spence 2008; Zampini, Sanabria, Phillips \& Spence 2007). The color of gelatin depends on the nature of the raw material used and whether the gelatin represents a first, second or further extraction (GMIA 2012). 
According to the standard, pastill should have the uniform color. Researchs have shown that there is a close relationship between hydrocolloids such as gelatin, starch and pectin, and color structures in food products (Saha \& Bhattacharya, 2001). The highest brightness index $\left(\mathrm{L}^{*}\right)$ was related to $100 \%$ industrial gelatin without fish gelatin, which had a significant difference with other treatments, which there was a significant difference with other treatments. This result is consistent with the results of some researchers (Ajandouz \& Puigserver 1999). The presence of fish gelatin in pastill formulation resulted in a more redness. Therefore, the type of gelatin had a significant effect on the color profile in pastill. Considering the higher average of $b^{*}$ value in treatments with higher fish gelatin ratio, it can be said that the yellow spectrum in these treatments was higher than that of industrial gelatin. One of the reasons can be attributed to the presence of carotenoids in fish tissues, which causes the trends to yellow color of treatments. Another reason can be related to Millard browning reactions (Dawson \& Acton 2017).

Specific carotenoids excist in fishes. The diverse carotenoids commonly occurring in fishes with different colours are tunaxanthein (yellow), lutein (greenish yellow), beta carotene (orange), doradexanthins (yellow), zeaxanthin (yellow orange), canthaxanthin (orange red), astaxanthin (red), eichinenone (red) and taraxanthin (yellow) (Theis, Salzburger, Egger 2012).

\section{Conclusion}

The use of fish gelatin such as Cyprinus carpio can play a critical role in and reducing waste and improving food quality. The results of this study showed that the treatment based on $75 \%$ fish gelatin had the highest protein, ash, phosphorus and iron content, hile the highest content of moisture and potassium were related to treatment based on $100 \%$ industrial gelatin. Therefore, fish gelatin had a more significant effect on protein and essential elements, especially phosphorus and iron, compared to the industrial type.

In terms of color parameters, the treatment containing $100 \%$ industrial gelatin showed the highest $\mathrm{L}^{*}$ value and the lowest $\mathrm{a}^{*}$ and $\mathrm{b}^{*}$ value. In other words, pastills produced with $100 \%$ industrial gelatin had a bright color in comparsion with those made from fish gelatin, which is considered as a defect in sensory evaluation of pastill.

\section{Acknowledgement}

This work was supported by the Laboratory of Science and Technology Park of Tehran University (Karaj). The researcher gratefully thanks Dr. Pooneh Amini Geram for her assistance in the experimental work.

\section{Conflict of interests}

The authors declare that there is no conflict of interest.

\section{References}

Abbasi S. Mohammadi S. \& Rahimi S. (2011) The partial replacement of gelatin with Persian gum and use the Boswellia Carterii Birdw to 
functional Pastill production. The Journal of Biosystem Engineering of Iran, 42 (1), 121-131.

Ajandouz E.H. \& Puigserver A. (1999) Nonenzymatic browning reaction of essential amino acids: Effect of $\mathrm{pH}$ on caramelization and Maillard reaction kinetics. Journal of Agricultural and Food Chemistry, 47(5), 17861793.

Bakar J. \& Harvinder K.G. (2002) Properties of gelatins from skins of fish-black tilapia (Oreochromis mossambicus) and red tilapia (Oreochromis nilotica). Food Chemistry, 77(1), 81-84.

Bakar J., Tan K. W., Hartina M. R. U. \& Ahmad A. B. (2011) Gelatins from three cultured freshwater fish skins obtained by liming process. Food Hydrocolloids, 25(5), 12561260.

Barrow C., \& Shahidi F. (Eds.). (2007) Marine nutraceuticals and functional foods. CRC Press. Taylor and Franc. ISBN9781574444872.

Boland A.B., Buhr K., Giannouli P. \& van Ruth, S. (2004) Influence of gelatine, starch, pectin and artificial saliva on the release of 11 flavour compounds from model gel systems. Food Chemistry, 86(3), 401-411.

Chen C. (2000) Factors which effect equilibrium relative humidity of agricultural products. Transactions of the American Society of Agricultural Engineers, 43(3), 673-683.

Cheow C. S., Sarbon N. M., Kyaw Z. Y. \& Howell N. K. (2007) Preparation and characterization of gelatins from the skins of sin croaker (Johnius dussumieri) and shortfin scad (Decapterus macrosoma). Food Chemistry, 101(1), 386-391.

Cho S. M., Kwak K. S., Park D. C., Gu Y. S., Ji C. I. \& Jang D. H. (2004) Processing optimization and functional properties of gelatin from shark (Isurus oxyrinchus) cartilage. Food Hydrocolloids, 18(4), 573579.

Curt C., Trystram G., Nogueira-Terrones H. \& Hossenlopp J. (2004) A method for the analysis and control of sensory properties during processing-application to the dry sausage process. Food control, 15(5), 341-349.

Dawson P.L. \& Acton J.C. (2017) Proteins in food processing.In:.Impact of protein on food color (ed. by Rickey y. yada). pp. 599-638. Elsevier inc.

Doublier J. L. \& Cuvelier G. (1996) Gums and HydrocoIIoids Functional Aspects. Carbohydrates in food, (74), 283.

El-Deen G. \& El-Shamery M. R. (2010) Studies on contamination and quality of fresh fish meats during storage. Academic journal of biological science, 2, 65-74.

GMIA (2012) Gelatin Handbook. Gelatin Manufacturers Institute of America, New York, 1-26.

Giménez B., Gómez-Guillén M.C. \& Montero P. (2005) The role of salt washing of fish skins in chemical and rheological properties of 
gelatin extracted. Food Hydrocolloids, 19(6), 951-957.

Grossman S. \& Bergman M. (1992) Process for the production of gelatin from fish skin. United States Patent. No. 5,093,474.

Gudmundsson M. \& Hafsteinsson H. (1997) Gelatin from cod skins as affected by chemical treatments. Journal of Food Science, 62(1), 3739.

Hansson A., Andersson J. \& Leufven A. (2001) The effect of sugars and pectin on flavour release from a soft drink-related model system. Food Chemistry, 72(3), 363-368.

Hao S., Li, L., Yang X., Cen J., Shi H., Bo Q. \& He J. (2009) The characteristic of gelatin extracted from sturgeon (Acipenser baeri) skin using various pretreatments. Food Chemistry, $115,124-128$.

Haug I.J., Draget K.I. \& Smidsrod O. (2004) Physical and rheological properties of fish gelatin compared to mammalian gelatin. Food Hydrocolloids, 18(2), 203-213.

Irwandi J., Faridayanti S., Mohamed E. S. M., Hamzah M. S., Torla H. H. \& Che Man Y. B. (2009) Extraction and characterization of gelatin from different marine fish species in Malaysia. International Food Research Journal, 16, 381-389.

ISIRI (Institute of Standards and Industrial Research of Iran), (2008) Yoghurt. ISIRI No. 9266. [In Persian]
ISIRI (Institute of Standards and Industrial Research of Iran), (2008) Determination of lead, cadmium, copper, Iron, and zinc - Atomic absorption spectrophotometry. $1^{\text {st }}$ edition, ISIRI No. 9266. [In Persian]

ISIRI (Institute of Standards and Industrial Research of Iran), (2008) Fruit Juice: Test methods. $1^{\text {st }}$ edition, ISIRI No. 9266. [In Persian]

Jesu prabhu A. (2015) Minerals in fish: does the source matter. PhD Thesis, Wageningen university.

Jim F., Garamumhango P. \& Musara C. (2017) Comparative Analysis of Nutritional Value of Oreochromis niloticus (Linnaeus), Nile Tilapia, Meat from Three Different Ecosystems. Journal of Food Quality, 1-8.

Karim A.A. \& Bhat R. (2009) Fish gelatin: Properties, challenges, and prospects as an alternative to mammalian gelatins. Food Hydrocolloids, 23(3), 563-576.

Kasankala L. M., Xue Y., Weilong Y., Hong S. D \& He Q. (2007) Optimization of gelatin extraction from grass carp (Catenopharyngodon idella) fish skin by response surface methodology. Bioresource Technology, 98(17), pp 3338-43.

Khosravi Darani K., Gholami Z. \& Gouveia L. (2017) Effect of Arthrospira platensis on the shelf life, sensorial and rheological properties of strudel. Romanian Biotechnological Letters, 22, 12250-12258. 
Kunachowicz H., Nadolna I., Przygoda B. \& Iwanow K. (2005) Tables of composition and nutritional value of food. Warszawa. PZWL. [in Polish]

Levitan C., Zampini M., Li, R. \& Spence C. (2008) Assessing the role of color cues and people's beliefs about color-flavor associations on the discrimination of the flavor of sugar-coated chocolates Chemical senses, 33, 415-423.

Lizarbe M.A. (1990) Characterization of hake (Merluccius merluccius L.) and trout (Salmo irideus Gibb.) collagen. Journal of Agricultural and Food chemistry, 38(3), 604-609.

Lombardi-Boccia G., Lanzi S. \& Aguzzi A. (2005) Aspects of meat quality: trace elements and $\mathrm{B}$ vitamins in raw and cooked meats. Journal of food Composition and Analysis, 18(1), 39-46.

Mariod A. A. \& Adam H. F. (2013) Gelatin, source, extraction and industrial applications. Acta Scientiarum Polonorum. Technologia Alimentaria, 12(2).

Montero P., Borderias J., Turnay J. Mariod A. A. \& Adam H. F. (2013) Gelatin, source, extraction and industrial applications. Acta Scientiarum Polonorum. Technologia Alimentaria, 12(2).

Montero P. \& Gomez-Guillen M.C. (2000) Extracting conditions for megrim (Lepidorhombus boscii) skin collagen affect functional properties of the resultant gelatine. Journal of Food Science, 65(3), 434-438.
Mostafa A.G.M., Shaltout O. E., Abdallah A. E. \& Osheba A. (2015) Physicochemical Characteristics of Gelatin Extracted from Catfish (Clarias gariepinus) and Carp (Cyprinus carpio) Skins. Middle East Journal of Agriculture Research, 4(2), 359-372.

Muyonga J.H., Colec C.G.B. \& Duodub K.G. (2004) Extraction and physicochemical characterisation of Nile perch (Lates niloticus) skin and bone gelatine. Food Hydrocolloids, 18(4): 581-592.

Nishimoto M., Sakamoto R., Mizuta S. \& Yoshinaka R. (2005) Identifi cation and characterization of molecular species of collagen in ordinary muscle and skin of the Japanese flounder (Paralichthys olivaceus). Journal of Food Chem, 90, 151-156.

Osborne R., Voigt M.N. \& Hall D.E. (1990) Utilization of lumpfish (Cyclopterus lumpus) carcasses for the production of gelatin. In: Advances in fisheries technology and biotechnology for increased profitability. Eds M.N.

Pittia P., Nicoli M.C. \& Sacchetti G. (2007) Effect of moisture and water activity on textural properties of raw and roasted coffee beans. Journal of texture studies, 38(1), 116-134.

Prabhu P. A. J. (2015) Minerals in fish: does the source matter? Wageningen University, The Netherlands.

Reh C., Gerber A., Prodolliet J. \& Vuataz G. (2006) Water content determination in green 
coffee-Method comparison to study specificity and accuracy. Food Chemistry, 96, 423-430.

Rustad T., Storrø I. \& Slizyte R. (2011) Possibilities for the utilisation of marine byproducts. International Journal of Food Science \& Technology, 46(10), 2001-2014.

Saha D. \& Bhattacharya S. (2010) Hydrocolloids as thickening and gelling agents in food: a critical review. Journal of food science and technology, 47(6), 587-597.

Stainsby G. (1987) Gelatin gels. In A. M. Pearson, T. R. Dutson, \& A. J. Bailey (Eds.), Advancesinmeatresearch,Vol.4:Collagenasafo od (pp. 209 e 222). New York: Van Nostrand Reinhold Company Inc.

Theis A., Salzburger W. \& Egger B. (2012) The function of anal fin egg-spots in the cichlid fish Astatotilapia burtoni. PloS ONE, 7(1), 29878.
Trindade Alfaro A., Balbinot E., Weber C. I., Tonial I. B. \& Machado-Lunkes A. (2014) Fish gelatin: Characteristics, functional properties, applications and future potentials. Food Engineering Reviews, 7(1), 33-44.

Tsami E. (1990) Heat of sorption of water in dried fruits. International Journal of Food Science and Technology, 25(6), 350359.

Weaver, C. M. (2013) Potassium and Health. Advances in Nutrition, 4(3), 368377.

Zampini M., Sanabria D., Phillips N. \& Spence C. (2007) The multisensory perception of flavor: Assessing the influence of color cues on flavor discrimination responses. Food Quality and Preference, 18(7), 975-984. 


\title{
تأثير جايخزينى زلاتين گاوى با زلاتين يوست ماهى كيور معمولى بر محتواى معدنى و خصوصيات
}

\section{رنگ در ياستيل فراسودمند}

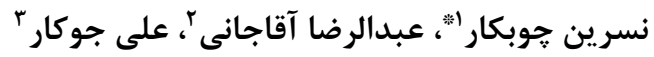 \\ ا كروه شيلات، دانشكده كشاورزى، واحدكرمانشاه، دانشخاه آزاد اسلامى، كرمانشاه، ايران \\ r كروه علوم و مهندسى صنايع غذايى، دانشكده مهندسى صنايع و مكانيك، واحد قزوين، دانشگاه آزاد اسلامى، قزوين، ايران \\ r ${ }^{r}$
}

جكيده

زلاتين يك منبع يروتئينى ارزشمند و يك هيدروكلوييد تجارى بوده كه به ويزه در صنايع غذايى، دارويى و عكاسى كاربرد دارد. زلاتينهاى تجارى اساساً از خوى بوده كه به دلايل مذهبى و يا از گاو به دليل خطر انتقال بيمارى جنون گاوى قابل يذيرش نيست، به همين دليل استخراج زلاتين از ماهى و به ويزه ضايعات آن به عنوان منبع جايكزين زلاتين تجارى اهمّيت قابل توجهى يافته است. در يزوهش حاضر، بعد از استخراج زلاتين از يوست ماهى برورشى قابل دسترس و به صرفه كيور معمولى، فرمولاسيون

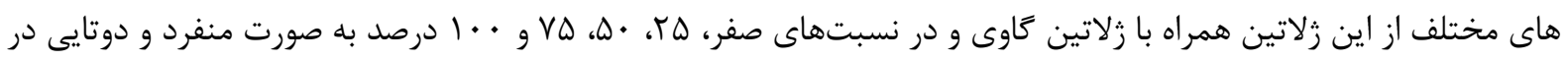
توليد پاستيل به كار رفت و در روز بعد از توليد به عنوان ييش تيمار، آزمايشهاى فيزيكوشيميايى شامل ميزان خاكستر، يروتئين، رطوبت، آهن، فسفر، روى و ليتيم و رنغ سنجى بر اساس بردازش تصوير بر روى نمونههاى باستيل امكان سنجى گرديد. نتايج نشان داد كه تيمار بر پايه له درصد زلاتين ماهى بيشترين ميزان رطوبت، يروتئين، فسفر، آهن، خاكستر و روى را داشت، در حالى كه بالاترين سطح پتاسيم و ليتيم مربوط به تيمار بر پايه .1 درصد زلاتين صنعتى (كاو) بود. تيمار صنعتى بالاترين

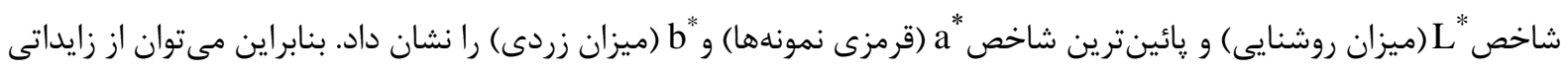
كه مصرف خاصى ندارند، زلاتينى با منشأ حلال و با املاح بالاتر فسفر و روى، با يروتئين بيشتر و با صرفه اقتصادى را جايكزين زلاتينهاى ديكر به ويزه در تنقلات مورد علاقه كودكان نمود.

كلمات كليدى: ياستيل، زلاتين يوست ماهى، زلاتين گاوى، رنغ سنجى، خصوصيات فيزيكوشيميايى "نويسنده مسئول: Nchoobkar20@gmail.com 